\title{
Health Care In The Suburbs: An Analysis Of Suburban Poverty And Health Care Access
}

\section{Citation}

Schnake-Mahl, Alina S., and Benjamin D. Sommers. 2017. "Health Care In The Suburbs: An Analysis Of Suburban Poverty And Health Care Access." Health Affairs 36 (10) (October 1): 17771785. doi:10.1377/hlthaff.2017.0545.

\section{Published Version}

doi:10.1377/hlthaff.2017.0545

\section{Permanent link}

http://nrs.harvard.edu/urn-3:HUL.InstRepos:34389685

\section{Terms of Use}

This article was downloaded from Harvard University's DASH repository, and is made available under the terms and conditions applicable to Open Access Policy Articles, as set forth at http:// nrs.harvard.edu/urn-3:HUL.InstRepos:dash.current.terms-of-use\#OAP

\section{Share Your Story}

The Harvard community has made this article openly available.

Please share how this access benefits you. Submit a story.

\section{Accessibility}


Health Care In The Suburbs: An Analysis Of Suburban Poverty And Health Care Access

Alina S. Schnake-Mahl and Benjamin D. Sommers 


\begin{abstract}
There are 16.9 million Americans living in poverty in the suburbs - more than in cities or rural communities. Despite recent increases in suburban poverty, the perception of the suburbs as areas of uniform affluence remains, and there has been little research into health care barriers experienced by people living in these areas. The objectives of this study were to compare patterns of insurance coverage and health care access in suburban, urban, and rural areas using national survey data from 2005 to 2015 and to compare outcomes by geography before and after the Affordable Care Act took effect. We found that nearly 40 percent of the uninsured population lived in suburban areas. Though unadjusted rates of health care access were better in suburban areas, compared to urban and rural communities, this advantage was greatly reduced after income and other demographics are accounted for. Overall, a substantial portion of the US population residing in the suburbs lacked health insurance and experienced difficulties accessing care. Increased policy attention is needed to address these challenges for vulnerable populations living in the suburbs.
\end{abstract}




\section{INTRODUCTION}

To many people, “suburbs” suggest sprawling post-World War II neighborhoods of predominantly white middle- and upper-class communities. ${ }^{1}$ This narrative persists, despite some heterogeneity in suburban populations and community types that has always existed in the suburbs ${ }^{2}$ and despite recent shifts in the geography of poverty and affluence in the United States. ${ }^{3,4}$ In fact, while rates of poverty are higher in cities, more poor Americans live in the suburbs than in cities or rural communities. ${ }^{4}$ In the 2000 s the number of poor residents in the suburbs of the largest metropolitan areas rose by 6.7 million, and by 2014 their number had reached 16.9 million -3 million more than the number of poor residents in urban areas. ${ }^{5}$

In the latter half of the twentieth century, the suburbs were home to predominantly white and relatively affluent populations. These residential patterns arose largely as a result of discriminatory housing policies and practices that incentivized whites' suburban homeownership and residence, to the exclusion of other racial groups. ${ }^{1}$ However, in recent years the suburbs have become home to populations of increasing economic and racial/ethnic diversity, because of several factors: economic restructuring during and after the great recession, a "return to the city" trend among Millennials and empty nesters and subsequent pricing out of lower-income families, more affordable suburban housing options, and direct international immigration to suburban communities. $^{2}$

Historically, rates of health insurance coverage have been higher in suburban areas than urban or rural areas, ${ }^{6}$ but the recent rapid uptick in suburban poverty has likely affected uninsurance rates in the suburbs, as people living below poverty are at high risk of being uninsured. $^{7}$ 
Additionally, substantial suburban unemployment and the rising number of immigrants in suburbs may contribute further to coverage challenges among suburbanites. ${ }^{7,8}$ Yet these issues have received little attention from health services researchers and policy makers.

Suburban residents, particularly those with lower incomes, may face unique barriers to health care access beyond simply lacking cover-age. Research has shown that residential context affects well-being and community health by shaping access and exposure to education, housing, social networks, transportation, employment, and health care. ${ }^{9}$ However, knowledge of how suburban poverty affects health is limited. While suburban poverty has become an area of increased policy interest, its implications for health remain unclear. To our knowledge, there has been limited research on the implications of the increasingly poor suburban population for health care access.

Other studies have highlighted the challenges of suburban poverty for social services, governance, institutions, and community-based programs. ${ }^{10,11}$ In particular, organizational resources targeted to the poor are more limited in suburban areas than elsewhere. ${ }^{12}$ While suburban social service providers have to cover larger delivery service areas than in urban areas, they now also face increased demand for services, which has risen rapidly since the recession. ${ }^{13}$ Additionally, despite substantial research on the impacts of the Affordable Care Act (ACA) for insurance and health care access, ${ }^{14,15}$ studies have not examined recent changes in these outcomes in suburban areas.

The objectives of this study were to compare patterns of insurance coverage and health care access in suburban, urban, and rural areas using national survey data from 2005 to 2015, and to compare outcomes by geography before and after the ACA took effect. We also conducted a subgroup analysis of these changes among low-income populations in these different 
geographies. We hypothesized that contrary to wide-spread assumptions about residents of suburbs, health care coverage and access to care are not substantially better in suburban areas than in rural or urban areas, though we hypothesized that these outcomes have improved in all three areas since the ACA's implementation. ${ }^{14,15}$

\section{METHODS}

\section{STUDY POPULATION AND METHODS}

Our study used data from the 2005-15 waves of the Behavioral Risk Factor Surveillance System (BRFSS), an annual national cross-sectional telephone survey of non institutionalized adults over age eighteen. ${ }^{16}$ With support from the Centers for Disease Control and Prevention and conducted at the state level, the BRFSS is the only publicly available, nationally representative survey that has both state and sub-state geographic identifiers and questions on health insurance and access to health care. Details about its methodology are available elsewhere. ${ }^{16}$

\section{SUBURBAN DEFINITION}

There is no gold standard or official definition of the suburbs. The Census Bureau defines suburbs as municipalities with more than 2,500 people in a Metropolitan Statistical Area (MSA) but located outside of census-identified "principal cities." Other research on suburban poverty has used variations of this definition ${ }^{.2,3,17}$ Across definitions, the finding of a general trend of increasing suburban poverty at the national level holds. ${ }^{3}$ However, there are substantial inter suburban differences in levels of poverty, even in neighboring areas. ${ }^{2}$ 
The BRFSS data set includes an indicator for Metropolitan status code, which is based on MSAs, or regions that generally include a central city, its suburbs, and other economically or socially linked communities. The Metropolitan status code indicator includes the following categories: center city of an MSA; outside the center city of an MSA but inside the county containing the center city; inside a suburban county of the MSA; in an MSA that has no center city; and not in an MSA. Our definition, referred to as Definition 1, is similar to the census definition, defining urban as the center city only. Suburban includes areas outside the center city of an MSA but inside the county containing the center city, as well as areas inside a suburban county of the MSA. Rural areas are those not within an MSA.

\section{SAMPLE}

Our sample contained nonelderly adults ages $18-64(n=3,259,300)$ in all fifty states. We excluded elderly adults because 98.9 percent are covered by Medicare. Additionally, we excluded 1,929 observations ( $<0: 001$ percent) from 2005 to 2011 that were missing Metropolitan status codes, since it is the main variable of interest. Finally, we included only the landline sample from the 2011-15 waves, excluding 555,851 cell-phone observations. In 2011 the BRFSS changed its sampling methodology to include cell phones, but cellphone observations lack a geographic indicator for Metropolitan status code. The 2015 BRFSS wave contains 1,906 observations collected in early 2016, which we included as part of our 2015 estimates; all other estimates refer to the year in which the survey was conducted.

\section{OUTCOME VARIABLES}

Following previous research using data from the BRFSS, ${ }^{18}$ we assessed access to health 
insurance coverage and access to health care using four measures: being uninsured, having no usual source of care (defined as lacking one or more personal doctors or health care providers), having an unmet care need due to cost in the past year, and having no receipt of a routine checkup in the past year. We modeled all of these outcomes as dichotomous, and all were defined so that higher values were worse (for example, percentage uninsured or without a usual source of care).

\section{STATISTICAL ANALYSIS}

We first compared the basic demographics of urban, suburban, and rural areas. Then we assessed changes over time in coverage and access for the three types of areas. Finally, we used logistic regression models to examine the association between the outcomes (access measures) and the three geographic areas, before and after adjustment for demographic factors (age, sex, race, ethnicity, marital status, education), employment, household income, survey year, and state of residence.

To estimate differential effects of the ACA associated with each of the three types of areas, we compared outcomes in the areas pre (2005-13) and post ACA (2014-15), also adjusting for a linear time trend and the additional covariates described above. For all regression analyses, we reported the odds ratio (OR) and $\mathrm{p}$ value. Analyses with associated $95 \%$ confidence intervals are in online Appendix Exhibits A1 and A2. ${ }^{19}$ We also produced predicted probabilities, calculated using Stata's "margins" command, for ease of interpretation. We stratified adjusted estimates into poor and nonpoor individuals (as described below), to assess for differential patterns by geography and poverty status.

We conducted additional analyses to test the sensitivity of our results to alternative 
definitions of suburban, as described in Appendix Exhibit A3. ${ }^{19}$ Family income was calculated as a percentage of the federal poverty level, based on annual income and the number of people in each family. We created the following income categories: poor (under 100 percent of poverty), near-poor (100-199 percent), middle class (200-299 percent), upper middle (300-399 percent), upper (400 percent or more), and income missing (12.2 percent of the data set). Observations with missing outcome responses were omitted from the sample for that particular analysis.

For all analyses, urban geography was the reference group.

The data were analyzed using Stata/SE 13.1. Analyses accounted for the BRFSS's complex survey design and used nationally representative survey weights. We also tested the effect of using robust standard errors clustering at the level of state-geography (for example, suburban areas in Massachusetts would be one cluster) in lieu of BRFSS survey-based standard errors.

\section{Limitations}

Although our study provides important comparisons of health care access in suburban, urban, and rural areas, several limitations must be acknowledged. First, our sample included only nonelderly adults, while other research in this area has not been age restricted. This limits comparison of our work with other reports.

Second, though the study relied on survey data, previous research has found high levels of reliability and validity for the BRFSS health care access questions. 18 Third, our household income measure was imprecise, since it was self-reported and measured in income categories rather than exact amounts; in addition, 12.2 percent of our sample did not provide any response to the income question. In our data, those with those with missing income were significantly 
more likely than others to be uninsured and have no usual source of care $(p<0: 001)$; thus, if anything, this omission may have led us to underestimate the suburban health care barriers in our sample.

Fourth, we excluded cell-phone respondents from our sample because data on our primary exposure, the geographic indicator, is lacking for this group. Fortunately, even after we excluded cell-phone respondents, the overall trend in the insurance rate in our data was similar to those found in other surveys of national insurance rates. ${ }^{7}$ Cell-phone use is more prevalent among low-income households. ${ }^{20}$ Therefore, our use of the landline-only sample may also have led to an underestimate of poverty rates and barriers to care.

Fifth, our assessment of changes after ACA implementation in 2014 are largely descriptive. We could not determine whether these changes in coverage rates were related directly to the ACA's coverage expansions or were due to unmeasured confounders. However, we did control for several potential confounders, including income, age, state, and the pre-2014 time trend.

Finally, the percentage of Asian respondents in the BRFSS is smaller than their representation in the US population, and the BRFSS does not include questions for nativity or immigration status. This is a potentially important factor, given that the share of suburban immigrants living in the largest metro areas increased from 56 percent to 61 percent between 2000 and 2013 - more than a 30 percent increase in the number of immigrants in the suburbs $^{21}$ - and that immigrants experience greater access challenges than their native-born counterparts. ${ }^{8}$ Though controlling for race, ethnicity, and other demographic factors should partially account for selective migration effects, future research on access challenges for immigrants in the suburbs would be informative. 


\section{RESULTS}

Our final data set included 2,701,520 observations. Exhibit 1 presents our descriptive analyses for suburban, urban and rural areas. Most demographic characteristics were similar across geographic area types. The largest portion of the population lived in the suburbs, and the smallest in rural areas. Educational attainment was highest in suburban areas, followed by urban. Our data show a greater percentage of non-Hispanic whites in suburban and rural locations, a lower rate of married individuals in urban areas, and a lower poverty rate in the suburbs.

\section{URBAN, SUBURBAN, AND RURAL LEVELS OF COVERAGE AND ACCESS}

We found that the suburbs were home to 43.9 percent of the population (Exhibit 1) and 38 percent of the uninsured population, based on an uninsurance rate of 15 percent. Exhibit 2 presents time trends of the mean uninsurance rate in the three geographic area types. Across all three, the trend was essentially flat from 2005 to 2010, after which the rate decreased. The uninsurance rate was initially lower in the suburbs, though the gap narrowed over time; by 2015 the rate in suburban areas was essentially the same as in urban areas.

Appendix Exhibits A4-A6 contain the time trends for three of the four access measures: having no usual source of care, having an unmet care need due to cost in the past year, and not receiving a routine checkup in the past year. ${ }^{19}$ For all three of these outcomes, the rates decreased across all geographic areas after 2014; by 2015 the gaps between urban and suburban areas had been eliminated for the first two measures.

\section{REGRESSION RESULTS}


Exhibit 3 presents our unadjusted, adjusted, and income-stratified regression estimates. Unadjusted rates for the suburbs were significantly lower in three of the four outcomes-being uninsured, having no usual source of care, and delaying care because of cost — than in urban areas. Across most outcomes, outcome rates were highest (worst) in rural areas. Access rates and the size of the disparity between suburban and other geographic areas differed by outcome; for example, the absolute difference between urban and rural areas was 4.5 percentage points for lacking a usual source of care, compared to 2.4 percentage points for delaying care because of cost.

The adjusted predicted probability of being uninsured was high across all geographic areas: over 15 percent overall and over 40 percent among the poor. The adjusted probability of having no usual source of care in the suburbs was 20.1 percent, and for no receipt of a routine checkup in the suburbs it was 34.7 percent. The suburban advantage for these outcomes was greatly attenuated after adjustment for income and other demographics; in fact, the odds of being uninsured were significantly higher for suburbs than urban areas after adjustment (OR: $1.027 ; \mathrm{p}<0: 05)$

Meanwhile, not surprisingly, access and coverage barriers were more common for poor adults than for higher-income adults, with odds ratios on "poor" ranging from 1.7 for no checkup to 8.14 for being uninsured. Among poor adults, the odds of the outcomes were close to 1.0 across geographic area types and were significantly higher in suburban areas for being uninsured. Thus, poor adults in the suburbs fared similarly to their poor counterparts in urban and rural areas. Overall, this indicates that sizable barriers to coverage and access exist among people in different income categories. After adjustment, 36.4 percent of low-income suburbanites had an unmet need due to cost, and 42.4 percent had not had a recent check-up, compared to 
15.7 percent and 34.7 percent for the full suburban population, respectively.

Exhibit 4 compares outcomes in each type of geographic region before and after implementation of the ACA. In all three types of areas, our coverage and access outcomes significantly improved in the post-ACA period. For suburban areas, there was a 3.8-percentagepoint drop in the uninsurance rate in the post ACA period compared to the pre-ACA trend; for urban areas, the comparable estimate was 4.6 percentage points, and for rural areas, it was 4.2 percentage points.

Sensitivity analyses with alternative definitions for suburban are in Appendix Exhibits A7 and A8, and analyses with standard errors clustered by state-geography are in Appendix Exhibit A9. ${ }^{19}$ Across these models, rates of coverage and access challenges remained high among low income adults in suburban areas, similar to those in urban and rural areas.

\section{DISCUSSION}

In this national study of patterns of health care access and insurance coverage, we found that people living in suburban areas encounter substantial barriers to care. Although the suburbs do have a small advantage over urban and rural areas for our unadjusted study measures, overall uninsurance rates there were not low, and access barriers were quite common, particularly for low-income adults. After adjustment for demographic differences by area, rates of access to care were similar across all geographic areas. This implies that living in the suburbs provides little if any protective effect, after income and other demographic features are taken into account.

Overall, nearly 40 percent of the uninsured population in the United States lives in the suburbs, and though the uninsurance rate is lower in suburban areas than in urban and rural locations, they are nonetheless substantial: Nearly one of every seven suburban residents is 
uninsured. Furthermore, as the overall uninsurance rate in the United States decreased and access improved in recent years, in large part because of the $\mathrm{ACA},{ }^{14,15}$ we found that the coverage and access gaps between urban and suburban areas essentially disappeared by 2015. Our analysis comparing the pre- and post-ACA periods appears to show differential change post ACA across these geographic areas, wherein coverage gains were greater in urban than suburban areas for some access measures. Despite improvements in access and coverage after the ACA took effect, our results also suggest that sizable barriers remain and that, if anything, gains may have been more limited in suburban areas.

\section{IMPLICATIONS FOR POLICY}

Our results show a large affordability gap based on income, with substantially worse access rates for the poor than the nonpoor across all geographies. Poverty in the suburbs likely poses unique challenges and consequences for residents, particularly for low-income and uninsured residents who seek care from the health care safety-net. Safety-net providers deliver care to uninsured, low-income, and other vulnerable populations, and as these populations increase in a geographic area, local need for these services also likely rises. Though our results do not enable us to comment directly on this issue, there is reason to suspect that unique nonfinancial barriers to care may exist in the suburbs, which may require different solutions than those needed in urban or rural areas. Previous research shows that even after area poverty rates are controlled for, services and publicly funded infrastructure targeted to the poor are scarce in many suburban areas. ${ }^{22}$ For instance, there are important gaps in the availability of health care services such as mental health, substance abuse treatment, and hospitals in suburban areas. ${ }^{23}$ And though care systems and provider networks are often and increasingly located in high-income 
suburban areas with large privately insured populations, ${ }^{11}$ many suburban physicians are less willing than their urban counterparts are to treat the uninsured and Medicaid beneficiaries, leaving poor suburban residents with limited options for physician care. ${ }^{23}$

Most policy approaches to bolster the health care safety net overlook the suburbs, focusing on urban and rural areas, which historically have had the greatest need. Many expansive suburban areas with large poor populations have few community health centers (CHCs) and small free clinics available. ${ }^{23}$ While some federally qualified health centers (FQHCs) are in some suburban areas, expanding FQHC capacity in areas with growing needs can be difficult. Location and funding for these health centers are dependent on Medically Underserved Area/Population (MUA/MUP) designation from the Health Resources and Services Administration, which is determined based on a metric combining area-level percentage of residents living in poverty and other indicators of care access and need. There are reports that some suburban areas attempting to gain MUA/MUP designation or establish FQHCs have been unable to do so because poor areas were balanced out by more affluent areas in the same census tract or because there were several large hospitals in the areas, giving the statistical appearance of sufficient provider capacity. ${ }^{23,24}$

Given the lack of health centers in suburban areas, emergency departments are often the Even accessing hospital or emergency care can be difficult for this population because of insufficient availability of safety-net hospitals, especially in high-poverty suburbs. ${ }^{11}$ Because fewer suburban providers appear to be willing to treat uninsured patients, suburban patients often must travel long distances to urban safety-net providers. ${ }^{25}$ On a broader scale, limited public transportation systems and sprawl in the suburbs may present unique barriers to low-income patients, given the long distances they must travel to obtain care. 
Current policies that identify areas of medical need and determine safety-net location have not adapted to shifts in the geography of poverty, which makes it difficult to locate services and providers in suburban areas with high levels of need for free or low-cost care. Recent proposals by some states to limit medical transportation services in Medicaid ${ }^{26}$ in particular could hamper access to care for suburban populations.

More generally, access and insurance gains post ACA were more limited in states that chose not to expand Medicaid. ${ }^{15}$ We found that 68 percent of the suburban population resided in expansion states, compared to 54 percent among rural populations and 42 percent among urban populations. The larger representation of suburban areas in expansion states indicates the importance of the ACA Medicaid expansion for the suburban population, along with the potential coverage and access losses if the expansion is repealed. Despite this disproportionate presence of suburbanites in expansion states, our findings indicate that the ACA has not differentially improved coverage and access for those in the suburbs.

\section{IMPLICATIONS FOR RESEARCH}

Most studies and reports on geographic disparities present urban-rural differences in health care access and outcomes, lumping suburban areas in with urban areas. For instance, a 2017 study comparing urban versus rural coverage rates in Medicaid expansion and nonexpansion states found that expansion increased the likelihood of insurance for low-income populations in both areas. ${ }^{27}$ Our study points to the need to consider suburban populations as well, particularly if the suburban poor population continues to increase. The potential technical differences in definition of suburban did not have a major impact on the trends identified in our analysis. Thus, which definition is used appears to be less critical than ensuring the identification 
of the suburbs as a geography independent of urban or rural areas. Such disaggregation by geography in survey design and data analysis is imperative for identifying, monitoring, and attempting to eliminate health disparities between populations living in different types of geographic areas. Given the heterogeneity that exists between types of suburbs, and the importance of census tract or area poverty level on service availability, ${ }^{22}$ future research should also consider how differences in income levels within suburbs may affect access to care. Given our data set, our analysis was able to examine only family-level poverty in assessing barriers to care. But poor neighborhoods themselves have critical implications for health and care access. Areas of concentrated poverty (that is, with poverty rates exceeding 40 percent) are beginning to present challenges to suburbia. ${ }^{28}$ Patterns of racial inequality typically seen in cities are being replicated in the suburbs, with suburban low-income communities of color facing lowperforming schools, poor public transport, limited economic opportunity, and minimal municipal

capacity or motivation to address poverty. ${ }^{4}$ These worrisome patterns reveal that more research is needed on the implications of concentrated suburban poverty and differential effects of suburban poverty by individual and community racial/ethnic composition.

\section{Conclusion}

This article contributes to a preliminary understanding of patterns of insurance coverage and access to care across suburban, urban, and rural areas of the United States. Our findings that nearly 40 percent of the uninsured live in the suburbs and that almost one in seven suburban residents is uninsured highlight the need for additional research in this area. We have shed some light on the large and growing number of poor Americans living in the suburbs, many of whom lack health insurance and experience difficulty gaining access to care. Overlooking the 
challenges faced by some residents of suburban areas - in particular, those with low incomesignores a large segment of the population. Increased attention to these issues will be critical to identifying the unique features of the suburbs that may present challenges to the health care safety net in serving vulnerable populations. 


\section{Exhibit 1}

Demographic characteristics in urban, suburban, and rural areas of the United States

\begin{tabular}{|c|c|c|c|}
\hline & Urban & Suburban & Rural \\
\hline Variable & $(\mathrm{N}=1,036,189)$ & $(\mathrm{N}=1,185,630)$ & $(\mathrm{N}=478,507)$ \\
\hline Total population & $38.37 \%$ & $43.91 \%$ & $17.72 \%$ \\
\hline Sex (male) & 48.94 & 48.46 & 48.65 \\
\hline \multicolumn{4}{|l|}{ Age (years) } \\
\hline $18-24$ & 13.37 & 12.50 & 13.07 \\
\hline $25-34$ & 20.23 & 18.32 & 18.43 \\
\hline $35-44$ & 22.86 & 23.89 & 20.89 \\
\hline $45-54$ & 23.65 & 25.06 & 24.69 \\
\hline $55-64$ & 19.89 & 20.24 & 22.92 \\
\hline \multicolumn{4}{|l|}{ Education } \\
\hline Less than high school & 12.12 & 9.34 & 12.44 \\
\hline High school diploma & 25.01 & 26.47 & 36.35 \\
\hline College or more & 62.30 & 63.75 & 51.00 \\
\hline DK/miss/ref & 0.47 & 0.44 & 0.21 \\
\hline Marital status & 55.60 & 63.89 & 62.92 \\
\hline Married & 54.97 & 62.90 & 62.09 \\
\hline Widowed/divorced & 17.27 & 15.28 & 18.13 \\
\hline Single & 27.76 & 21.80 & 19.79 \\
\hline Working & 66.17 & 68.83 & 65.80 \\
\hline \multicolumn{4}{|l|}{ Race } \\
\hline White & 67.77 & 79.95 & 85.38 \\
\hline Black & 16.42 & 8.76 & 7.18 \\
\hline Asian & 1.53 & 1.07 & 0.39 \\
\hline Other race & 11.74 & 8.63 & 5.92 \\
\hline $\mathrm{DK} / \mathrm{miss} / \mathrm{ref}$ & 2.61 & 1.59 & 1.14 \\
\hline \multicolumn{4}{|l|}{ Ethnicity } \\
\hline Hispanic & 19.78 & 13.26 & 6.68 \\
\hline Non-Hispanic & 75.32 & 82.70 & 89.61 \\
\hline $\mathrm{DK} / \mathrm{miss} / \mathrm{ref}$ & 4.90 & 4.04 & 3.71 \\
\hline \multicolumn{4}{|l|}{ Income level } \\
\hline Poor & 15.61 & 11.11 & 14.71 \\
\hline Near-poor & 17.03 & 14.60 & 21.21 \\
\hline Middle class & 12.50 & 12.78 & 16.56 \\
\hline Upper middle class & 7.31 & 7.55 & 8.95 \\
\hline Upper class & 35.32 & 42.06 & 25.62 \\
\hline DK/NS/miss/ref & 12.22 & 11.87 & 12.94 \\
\hline
\end{tabular}

SOURCE Authors' analysis of data from the Behavioral Risk Factor Surveillance System, 2005-15 (see Note 16 in text). NOTES Our definition of suburban is in the text. All results are significant $(p<0: 001)$ using chi-square tests for differences in each demographic variable across the three types of geographic areas. DK/NS/miss/ref indicates Don’t know/not sure/missing/refused. 


\section{Exhibit 2}

Uninsurance rates among nonelderly adults in urban, suburban, and rural areas, 2005-15 $25 \%-$

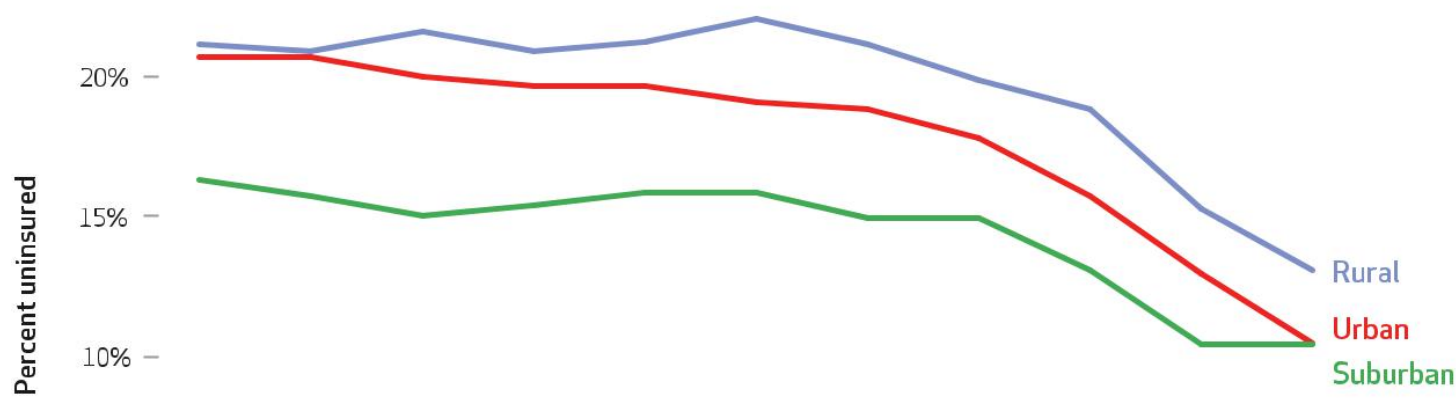

$5 \%-$

\begin{tabular}{|c|c|c|c|c|c|c|c|c|c|c|}
\hline $\begin{array}{c}1 \\
2005\end{array}$ & $\begin{array}{c}1 \\
2006\end{array}$ & $\begin{array}{c}1 \\
2007\end{array}$ & $\begin{array}{c}1 \\
2008\end{array}$ & $\begin{array}{c}1 \\
2009\end{array}$ & $\begin{array}{c}1 \\
2010\end{array}$ & $\begin{array}{c}1 \\
2011\end{array}$ & $\begin{array}{c}1 \\
2012\end{array}$ & $\begin{array}{c}1 \\
2013\end{array}$ & $\begin{array}{c}1 \\
2014\end{array}$ & $\begin{array}{c}1 \\
2015\end{array}$ \\
\hline
\end{tabular}

SOURCE Authors' analysis of data from the Behavioral Risk Factor Surveillance

System, 2005-15 (see Note 16 in text). NOTE Our definition of suburban is in the text. 
Exhibit 3: Predicted probabilities and odds ratios for coverage and access-to-care barriers in urban, suburban, and rural areas of the United States

\begin{tabular}{|c|c|c|c|c|c|}
\hline & $\begin{array}{l}\text { Urban (ref) } \\
\text { Predicted } \\
\text { probability (\%) }\end{array}$ & Suburban & $\begin{array}{l}\text { Predicted } \\
\text { probability (\%) }\end{array}$ & Odds ratio & $\begin{array}{l}\text { Predicted } \\
\text { probability (\%) }\end{array}$ \\
\hline \multicolumn{6}{|l|}{ Uninsured } \\
\hline Unadjusted & 18.66 & $0.770 * * * *$ & 14.99 & $1.117 * * *$ & 20.37 \\
\hline Adjusted $^{\mathrm{a}}$ & 16.83 & $1.027 * *$ & 17.13 & $1.190^{* * * *}$ & 18.88 \\
\hline Among the poor ${ }^{\mathrm{a}}$ & 41.13 & $1.061 * *$ & 41.24 & 1.024 & 41.66 \\
\hline \multicolumn{6}{|c|}{ No usual source of care } \\
\hline \begin{tabular}{|l|} 
Unadjusted \\
\end{tabular} & 23.47 & $0.765 * * * *$ & 19.01 & $0.859 * * * *$ & 20.86 \\
\hline Adjusted $^{\mathrm{a}}$ & 22.68 & $0.936 * * * *$ & 20.08 & $0.947 * * * *$ & 19.81 \\
\hline Among the poor ${ }^{\mathrm{a}}$ & 40.29 & $0.925^{* *}$ & 38.64 & $0.805 * * * *$ & 35.80 \\
\hline \multicolumn{6}{|c|}{ Unmet need due to cost } \\
\hline Unadjusted & 16.68 & $0.830 * * * *$ & 14.16 & $1.072 * * * *$ & 17.57 \\
\hline Adjusted $^{\mathrm{a}}$ & 15.54 & $1: 011$ & 15.68 & $-1.032 * *$ & 15.93 \\
\hline Among the poor ${ }^{\mathrm{a}}$ & 33.65 & 1.035 & 36.39 & 0.978 & 35.15 \\
\hline \multicolumn{6}{|c|}{ No receipt of a routine checkup } \\
\hline Unadjusted & 34.11 & 0.993 & 33.96 & $1.147 * * * *$ & 37.26 \\
\hline Adjusted $^{\mathrm{a}}$ & 33.96 & $1.035 * * * *$ & 34.70 & $1.089 * * * *$ & 35.77 \\
\hline Among the poor ${ }^{\mathrm{a}}$ & 41.53 & 1.041 & 42.44 & 1.037 & 42.35 \\
\hline
\end{tabular}

SOURCE Authors' analysis of data from the Behavioral Risk Factor Surveillance System, 2005-15 (see Note 16 in text). NOTE Our definition of suburban is in the text. ${ }^{a}$ Analyses adjusted for year, education, employment, marriage status, age, race, ethnicity, state, and federal poverty level category. ${ }^{* *} \mathrm{p}<0: 05 * * * \mathrm{p}<0: 01 * * * * \mathrm{p}<0$ :001 
Exhibit 4: Predicted probabilities and odds ratios for coverage and access, before (2005-13) and after (2014-15) implementation of the Affordable Care Act (ACA) in urban, suburban, and rural areas of the United States

\begin{tabular}{|c|c|c|c|c|c|c|}
\hline & Urban & & Suburban & & Rural & \\
\hline & Odds ratio & $\begin{array}{l}\text { Predicted } \\
\text { probability } \\
(\%)\end{array}$ & Odds ratio & $\begin{array}{l}\text { Predicted } \\
\text { probability } \\
(\%)\end{array}$ & Odds ratio & $\begin{array}{l}\text { Predicted } \\
\text { probability } \\
(\%)\end{array}$ \\
\hline \multicolumn{7}{|l|}{ |Uninsured } \\
\hline Pre ACA & Ref & 17.51 & Ref & 17.45 & Ref & 17.41 \\
\hline Post ACA & $0.646^{* * * *}$ & 12.89 & $0.702 * * * *$ & 13.64 & $0.679 * * *$ & 13.29 \\
\hline \multicolumn{7}{|c|}{ No usual source of care } \\
\hline & & & & & & \\
\hline Pre ACA & Ref & 21.07 & Ref & 21.03 & Ref & 21.02 \\
\hline Post ACA & 0.965 & 20.56 & $1.058 * *$ & 21.85 & $1.147 * * * *$ & 23.04 \\
\hline \multicolumn{7}{|c|}{ Unmet need due to cost } \\
\hline Pre ACA & Ref & 15.81 & Ref & 15.77 & Ref & 15.73 \\
\hline Post ACA & $0.735 * * * *$ & 12.47 & $0.774 * * * *$ & 12.96 & $0.763 * * * *$ & 12.77 \\
\hline \multicolumn{7}{|c|}{ No receipt of a routine checkup } \\
\hline Pre ACA & Ref & 34.66 & Ref & 34.63 & Ref & 34.63 \\
\hline Post ACA & $0.937 * * * *$ & 33.29 & $0.963 * *$ & 33.82 & $0.919 * * * *$ & 32.86 \\
\hline
\end{tabular}

SOURCE Authors' analysis of data from the Behavioral Risk Factor Surveillance System, 200515 (see Note 16 in text). NOTES Our definition of suburban is in the text. Analyses adjusted for year, education, employment, marriage status, age, race, ethnicity, federal poverty level category, and pre-ACA trend. Odds ratios represent the odds of the outcomes, comparing post ACA to pre ACA, for each geographic area. $* * p<0: 05 * * * p<0: 01 * * * * p<0: 001$ 


\section{NOTES}

1 Frey WH. Melting pot cities and suburbs: racial and ethnic change in metro America in the 2000s. Washington (DC): Brookings Institution, Metropolitan Policy Program; 2011 May 4.

2 Pooley KB. Debunking the "cookiecutter" myth for suburban places and suburban poverty: analyzing their variety and recent trends. In: Anacker KB, editor. The new American suburb: poverty, race, and the economic crisis. New York (NY): Ashgate; 2015. p. 39.

3 Kneebone E, Berube A. Confronting suburban poverty in America. Washington (DC): Brookings Institution Press; 2013.

4 Kneebone E. The growth and spread of concentrated poverty, 2000 to 2008-2012. Washington (DC): Brookings Institution; 2014.

5 Allard SW. Places in need: the changing geography of poverty. New York (NY): Russell Sage Foundation; 2017.

6 Institute of Medicine. A shared destiny: community effects of uninsurance. Washington (DC): National Academies Press; 2002.

7 Kaiser Commission on Medicaid and the Uninsured. Key facts about the uninsured population [Internet]. Washington (DC): Henry J. Kaiser Family Foundation; 2015 Oct [cited 2017 Aug 15]. Available from: http:// files.kff.org/attachment/fact-sheetkey- facts-about-theuninsuredpopulation

8 Schur CL, Feldman JJ. Running in place: how job characteristics, immigrant status, and family structure keep Hispanics uninsured: New York (NY): Commonwealth Fund, Task Force on the Future of Health Insurance; 2001.

9 National Academies of Sciences, Engineering and Medicine. Communities in action: pathways to health equity. Washington (DC): National Academies Press; 2017.

10 Roth BJ, Allard SW. The response of the nonprofit safety net to rising suburban poverty. London: Ashgate; 2015.

11 Andrulis DP, Duchon LM. The changing landscape of hospital capacity in large cities and suburbs: implications for the safety net in metropolitan America. J Urban Health. 2007;84(3):400-14.

12 Murphy AK, Wallace D. Opportunities for making ends meet and upward mobility: differences in organizational deprivation across urban and suburban poor neighborhoods. Soc Sci Q. 2010;91(5):1164-86.

13 Allard SW, Roth B. Strained suburbs: the social service challenges of rising suburban poverty.Washington (DC): Brookings Institution; 2010.

14 Sommers BD, Buchmueller T, Decker SL, Carey C, Kronick R. The Affordable Care Act has led to significant gains in health insurance and access to care for young adults. Health Aff (Millwood). 2013;32(1): 165-74.

15 Sommers BD, Gunja MZ, Finegold K, Musco T. Changes in self-reported insurance coverage, access 
to care, and health under the Affordable Care Act. JAMA. 2015;314(4):366-74.

16 Centers for Disease Control and Prevention. Behavioral Risk Factor Surveillance System: annual survey data [Internet]. Atlanta (GA): CDC; [page last reviewed 2017 Aug 25; cited 2017 Aug 31]. Available from: https://www.cdc.gov/brfss/annual data/annual_data.htm

17 Lee S, Leigh NG, McMillan A. Metropolitan growth patterns and innerring suburban decline: longitudinal analysis (1980-2007) for the 100 large U.S. metropolitan areas. In: Anacker KB, editor. The new American suburb: poverty, race, and the economic crisis. New York (NY): Ashgate; 2015. p. 153-74.

18 Pierannunzi C, Hu SS, Balluz L. A systematic review of publications assessing reliability and validity of the Behavioral Risk Factor Surveillance System (BRFSS), 2004-2011.

BMC Med Res Methodol. 2013; 13(1):49.

19 See Appendix.

20 Christian L, Keeter S, Purcell K, Smith A, editors. Assessing the cellphone challenge to survey research in 2010. Presentation to: Annual meeting of the American Association for Public Opinion Research; 2010 May 13-16; Chicago, Illinois.

21 Wilson HJ, Singer A. Immigrants in 2010 metropolitan America: a decade of change. Washington (DC): Brookings Institution; 2011.

22 Allard SW. Access to social services: the changing urban geography of poverty and service provision. Washington (DC): Brookings Institution, Center on Urban and Metropolitan Policy, Survey Series; 2004.

23 Felland LE, Lauer JR, Cunningham PJ. Suburban poverty and the health care safety net [Internet]. Washington (DC): Center for Studying Health System Change; 2009 Jul [cited 2017 Aug 31]. (Research Brief No. 13). Available from: http://hschange .org/CONTENT/1074/?topic=topic27

24 Katz A, Felland LE, Hill I, Stark LB. A long and winding road: federally qualified health centers, community variation and prospects under reform [Internet]. Washington (DC): Center for Studying Health System Change; 2011 Nov [cited 2017 Aug31]. (Research Brief No. 21). Available from: http://hschange.org/ CONTENT/1257/?topic=topic27

25 Tomer A, Kneebone E, Puentes R, Berube A. Missed opportunity: transit and jobs in metropolitan America. Washington (DC): Brookings Institution; 2011.

26 Indiana Family and Social Services Administration. Healthy Indiana Plan (HIP) section 1115 waiver extension application [Internet]. Indianapolis (IN): Indiana FSSA; 2016 Dec 20 [cited 2017 Aug 15]. Available from: https://www.in.gov/fssa/hip/ files/HIP_Extension_Waiver.pdf

27 Soni A, Hendryx M, Simon K. Medicaid expansion under the Affordable Care Act and insurance coverage in rural and urban areas. J Rural Health. 2017;33(2):217-26.

28 Kneebone E, Nadeau CA. The resurgence of concentrated poverty in America: metropolitan trends in the 2000s [Internet]. Washington (DC): Brookings Institution; 2011 Nov 3 [cited 2017 Aug 15].

Available from: https://www.brookings.edu/ research/the-re-emergence-ofconcentrated-

poverty-metropolitantrends-in-the-2000s/ 


\section{Appendix}

Appendix Exhibit A1: Predicted probabilities and odds ratios for coverage and access to care barriers in urban, suburban, and rural areas of the United States (Including 95\% CI)

\begin{tabular}{|c|c|c|c|c|c|c|c|}
\hline & & Urban (Ref) & & Suburban & & Rural & \\
\hline & & $\begin{array}{l}\text { Odds Ratio } \\
\text { (Predicted } \\
\text { Probability) }\end{array}$ & $95 \% \mathrm{Cl}$ & $\begin{array}{c}\text { Odds Ratio (Predicted } \\
\text { Probability) }\end{array}$ & $95 \% \mathrm{Cl}$ & $\begin{array}{l}\text { Odds Ratio } \\
\text { (Predicted } \\
\text { Probability) }\end{array}$ & $95 \% \mathrm{Cl}$ \\
\hline \multirow{3}{*}{ Uninsured } & Unadjusted & $1(18.66 \%)$ & Ref & $0.770^{* * * *}(14.99)$ & $(0.756,0.784)$ & $1.117^{* * *}(20.37 \%)$ & $(1.097,1.137)$ \\
\hline & Adjusted $^{\mathrm{a}}$ & $1(16.83 \%)$ & Ref & $1.027^{* *}(17.13 \%)$ & $(1.005,1.049)$ & $1.190^{* * * *}(18.88 \%)$ & $(1.164,1.214)$ \\
\hline & $\begin{array}{c}\text { Among the } \\
\text { poor }^{\text {a }}\end{array}$ & $1(41.13 \%)$ & Ref & $1.061^{* *}(41.24 \%)$ & $(1.013,1.112)$ & $1.024(41.66 \%)$ & $(0.979,1.072)$ \\
\hline \multirow{3}{*}{$\begin{array}{l}\text { No Usual } \\
\text { Source of } \\
\text { Care }\end{array}$} & Unadjusted & $1(23.47 \%)$ & Ref & $0.765^{* * * *}(19.01 \%)$ & $(0.752,0.778)$ & $0.859^{* * * *}(20.86 \%)$ & $(0.845,0.874)$ \\
\hline & Adjusted $^{\mathrm{a}}$ & $1(22.68 \%)$ & Ref & $0.936^{* * * *}(20.08 \%)$ & $(0.919,0.953)$ & $0.947^{* * * *}(19.81 \%)$ & $(0.929,0.966)$ \\
\hline & $\begin{array}{c}\text { Among the } \\
\text { poor }^{\text {a }}\end{array}$ & $1(40.29 \%)$ & Ref & $0.925^{* *}(38.64 \%)$ & $(0.881,0.971)$ & $0.805^{* * * *}(35.8 \%)$ & $(0.767,0.846)$ \\
\hline \multirow{3}{*}{$\begin{array}{l}\text { Unmet Need } \\
\text { due to cost }\end{array}$} & Unadjusted & $1(16.68 \%)$ & Ref & $0.830^{* * * *}(14.16 \%)$ & $(0.815,0.845)$ & $1.072^{* * * *}(17.57 \%)$ & $(1.054,1.091)$ \\
\hline & Adjusted $^{\mathrm{a}}$ & $1(15.54 \%)$ & Ref & $1.011(15.68 \%)$ & $(0.988,1.084)$ & $1.032^{*}(15.93 \%)$ & $(1.012,1.053)$ \\
\hline & $\begin{array}{c}\text { Among the } \\
\text { poor }^{\text {a }}\end{array}$ & $1(33.65 \%)$ & Ref & $1.035(36.39 \%)$ & $(0.988,1.084)$ & $0.978(35.15 \%)$ & $(0.935,1.022)$ \\
\hline \multirow{3}{*}{$\begin{array}{c}\text { No Receipt of } \\
\text { a Routine } \\
\text { Checkup }\end{array}$} & Unadjusted & $1(34.11 \%)$ & Ref & $0.993(33.96 \%)$ & $(0.980,1.006)$ & $1.147^{* * * *}(37.26 \%)$ & $(1.132,1.163)$ \\
\hline & Adjusted $^{\mathrm{a}}$ & $1(33.96 \%)$ & Ref & $1.035^{* * * *}(34.7 \%)$ & $(1.021,1.05)$ & $1.089^{* * * *}(35.77 \%)$ & (1.073 1.105) \\
\hline & $\begin{array}{c}\text { Among the } \\
\text { poor }^{\text {a }}\end{array}$ & $1(41.53 \%)$ & Ref & $1.041(42.44 \%)$ & $(0.954,1.086)$ & $1.037(42.35 \%)$ & $(0.991,1.085)$ \\
\hline
\end{tabular}

SOURCE: Authors' analysis of data from the Behavioral Risk Factor Surveillance System, 2005-15 (see Note 16 in text). NOTE: Uses Definition 1 of suburban, in the text ${ }^{a}$ Analysis adjusted for year, education, employment, marriage status, age, race, ethnicity, state and Federal Poverty level category. $\mathrm{Cl}$ is confidence interval. ${ }^{* *} \mathrm{p}<0.5^{* * *} \mathrm{p}<.01{ }^{* * * *} \mathrm{p}<.001$ 
Appendix Exhibit A2: Predicted Probabilities and Odds Ratios for Coverage and Access, Pre ACA (2005-2013) and Post ACA (2014-2015) Implementation, by Geographic Area (Including 95\% CI)

\begin{tabular}{|c|c|c|c|c|c|c|c|}
\hline & & \multicolumn{2}{|l|}{ Urban } & \multicolumn{2}{|c|}{ Suburban } & \multicolumn{2}{|l|}{ Rural } \\
\hline & & $\begin{array}{l}\text { Odds Ratio (Predicted } \\
\text { Probability) }\end{array}$ & $95 \% \mathrm{Cl}$ & $\begin{array}{l}\text { Odds Ratio } \\
\text { (Predicted } \\
\text { Probability) }\end{array}$ & $95 \% \mathrm{Cl}$ & $\begin{array}{l}\text { Odds Ratio (Predicted } \\
\text { Probability) }\end{array}$ & $95 \% \mathrm{Cl}$ \\
\hline \multirow{2}{*}{ Uninsured } & $\begin{array}{l}\text { Pre } \\
\text { ACA }\end{array}$ & $1(17.51 \%)$ & Ref & $1(17.45 \%)$ & Ref & $1(17.41 \%)$ & Ref \\
\hline & $\begin{array}{l}\text { Post } \\
\text { ACA }\end{array}$ & $0.646^{* * * *}(12.89 \%)$ & $(0.614,0.681)$ & $0.702^{* * * *}(13.64 \%)$ & $(0.663,0.744)$ & $0.679^{* * *}(13.29 \%)$ & $(0.642,0.744)$ \\
\hline \multirow{2}{*}{$\begin{array}{l}\text { No Usual } \\
\text { Source of } \\
\text { Care }\end{array}$} & $\begin{array}{l}\text { Pre } \\
\text { ACA }\end{array}$ & $1(21.07 \%)$ & Ref & $1(21.03 \%)$ & Ref & $1(21.02 \%)$ & Ref \\
\hline & $\begin{array}{l}\text { Post } \\
\text { ACA }\end{array}$ & $0.965(20.56 \%)$ & $(0.924,1.007)$ & $1.058^{* *}(21.85 \%)$ & $(1.009,1.110)$ & $1.147^{* * * *}(23.04 \%)$ & $(1.093,1.204)$ \\
\hline \multirow{2}{*}{$\begin{array}{l}\text { Unmet Need } \\
\text { due to cost }\end{array}$} & $\begin{array}{l}\text { Pre } \\
\text { ACA }\end{array}$ & $1(15.81 \%)$ & Ref & $1(15.77 \%)$ & Ref & $1(15.73 \%)$ & Ref \\
\hline & $\begin{array}{l}\text { Post } \\
\text { ACA }\end{array}$ & $0.735^{* * * *}(12.47 \%)$ & $(0.702,0.769)$ & $0.774 *^{* * *}(12.96 \%)$ & $(0.737,0.814)$ & $0.763^{* * * *}(12.77 \%)$ & $(0.725,0.802)$ \\
\hline \multirow{2}{*}{$\begin{array}{l}\text { No Receipt } \\
\text { of a Routine } \\
\text { Checkup }\end{array}$} & $\begin{array}{l}\text { Pre } \\
\text { ACA }\end{array}$ & $1(34.66 \%)$ & Ref & $1(34.63 \%)$ & Ref & $1(34.63 \%)$ & Ref \\
\hline & $\begin{array}{l}\text { Post } \\
\text { ACA }\end{array}$ & $0.937^{* * * *}(33.29 \%)$ & $(0.907,0.968)$ & $0.963 *^{*}(33.82 \%)$ & $(0.930,0.996)$ & $0.919^{* * * *}(32.86 \%)$ & $(0.886,0.953)$ \\
\hline
\end{tabular}

SOURCE: Authors' analysis of data from the Behavioral Risk Factor Surveillance System, 2005-15 (see Note 16 in text). NOTE: Uses Definition 1 of suburban, in the text. Analyses adjusted for year, education, employment, marriage status, age, race, ethnicity, Federal poverty Level category and pre ACA trend. Odds ratios represent the odds of the outcomes, comparing post ACA to pre ACA, for each geographic area. CI is confidence interval. ${ }^{* *} \mathrm{p}<0.5^{* * *} \mathrm{p}<.01^{* * * *} \mathrm{p}<.001$ 
Appendix Exhibit A3: Alternative Definitions of Suburban Areas

\section{Definition 2:}

- "Urban" includes both the center city and area within a county with a center city that is urban. "Suburban" includes only suburban counties of an MSA (similar to definition by Allard and Roth). Rural" is defined as not within a MSA.

Definition 3:

- Urban" is limited to the center city of an MSA, while the suburbs are divided into two categories - the inner suburb that is beyond the city center but with the county containing the center city, and the outer suburb, which is any suburban county of the MSA. Rural" is defined as not within a MSA. 
Appendix Exhibit A4: Rate of No Usual Source of Care Among Non-Elderly Adults in Urban, Suburban and Rural Areas (2005-2015)

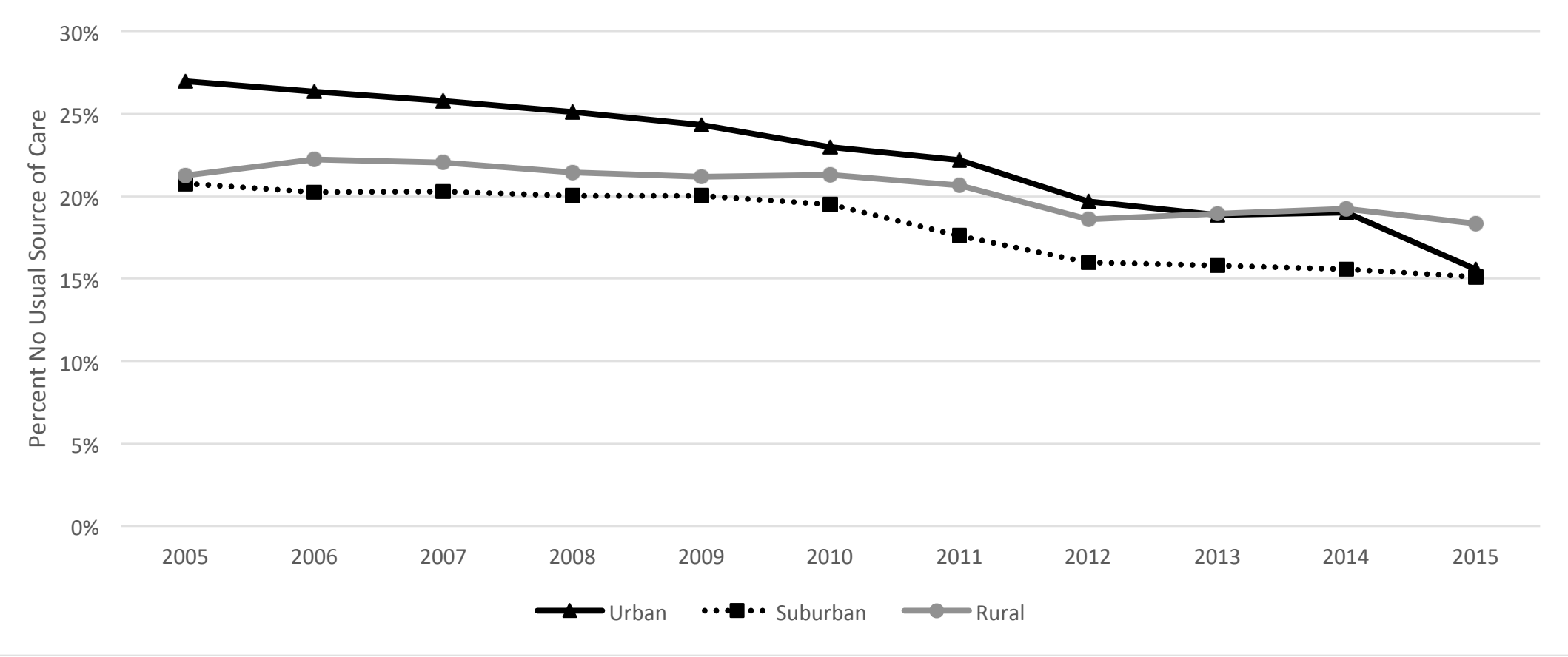

SOURCE Authors' analysis of data from the Behavioral Risk Factor Surveillance System, 2005-15 (see Note 16 in text). NOTE Uses Definition 1 of suburban, in the text. 
Appendix Exhibit A5: Rate of Delayed Care because of Cost in the Past Year Among Non-Elderly Adults in Urban, Suburban and Rural Areas (2005-2015)

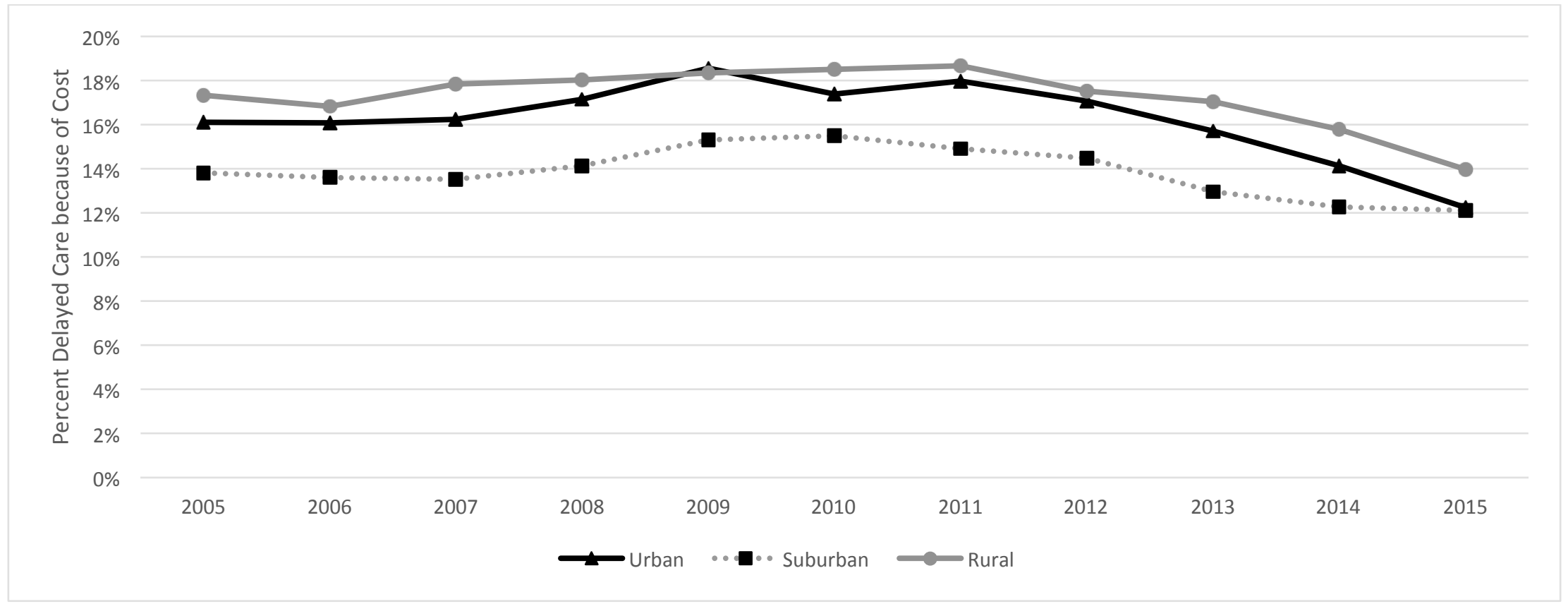

SOURCE Authors' analysis of data from the Behavioral Risk Factor Surveillance System, 2005-15 (see Note 16 in text).

NOTE Uses Definition 1 of suburban, in the text 
Appendix Exhibit A6: Rate of No Check up in the Past Year Among Non-Elderly Adults in Urban, Suburban and Rural Areas (2005-2015)

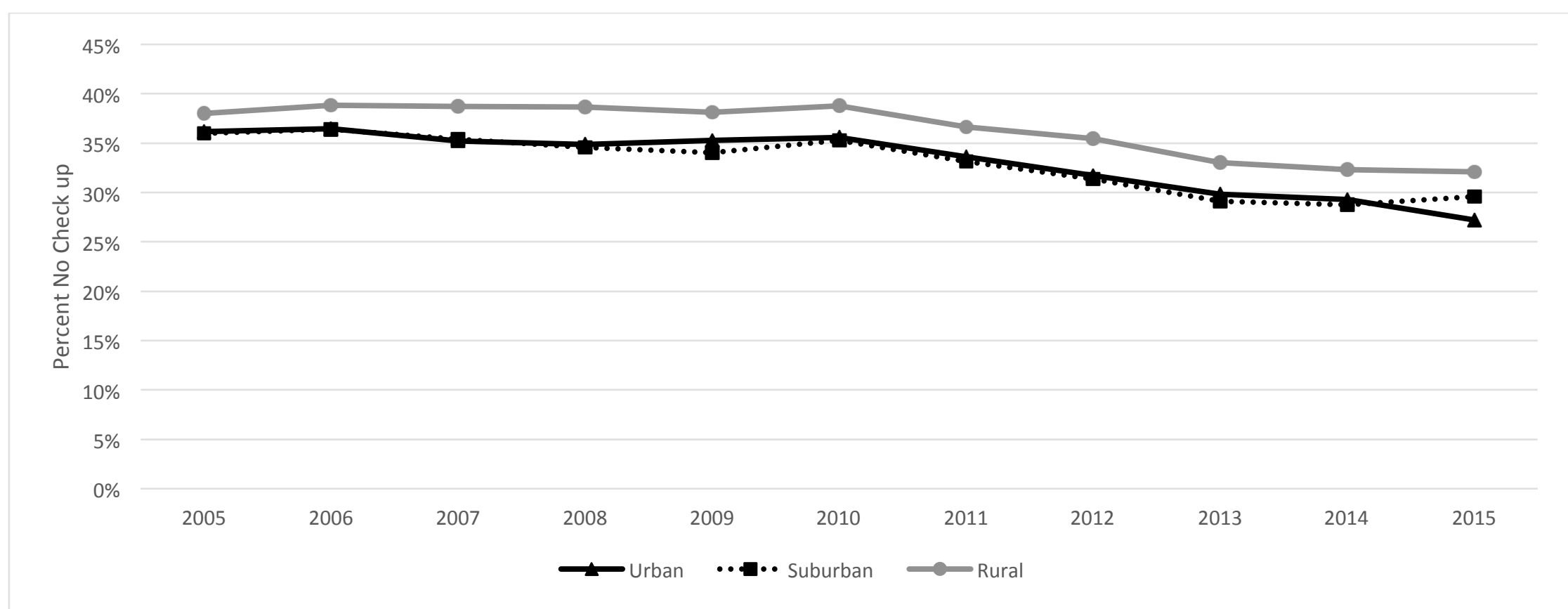

SOURCE Authors' analysis of data from the Behavioral Risk Factor Surveillance System, 2005-15 (see Note 16 in text).

NOTE Uses Definition 1 of suburban, in the text 
Appendix Exhibit A7: Predicted Probabilities and Odds Ratios for Coverage and Access to Care Barriers, in urban, suburban and rural areas of the United States (Suburban Definition 2)

\begin{tabular}{|c|c|c|c|c|c|c|c|}
\hline & & \multicolumn{2}{|c|}{ Urban (Ref) } & \multicolumn{2}{|c|}{ Suburban } & \multicolumn{2}{|c|}{ Rural } \\
\hline & & $\begin{array}{l}\text { Odds Ratio } \\
\text { (Predicted } \\
\text { Probability) }\end{array}$ & $\begin{array}{c}95 \% \\
\mathrm{Cl}\end{array}$ & $\begin{array}{l}\text { Odds Ratio } \\
\text { (Predicted } \\
\text { Probability) }\end{array}$ & $95 \% \mathrm{Cl}$ & $\begin{array}{l}\text { Odds Ratio } \\
\text { (Predicted } \\
\text { Probability) }\end{array}$ & $95 \% \mathrm{Cl}$ \\
\hline \multirow{3}{*}{ Uninsured } & Unadjusted & $1(17.20 \%)$ & Ref & $0.822^{* * * *}(14.58 \%)$ & $(0.903,0.840)$ & $1.232^{* * * *}(20.38 \%)$ & $(1.212,1.252)$ \\
\hline & Adjusted $^{\mathrm{a}}$ & $1(16.68 \%)$ & Ref & $1.061^{* * * *}(17.54 \%)$ & $(1.035,1.088)$ & $1.19^{* * * *}(18.91 \%)$ & $(1.167,1.213)$ \\
\hline & Among the poor ${ }^{\mathrm{a}}$ & $1(42.08 \%)$ & Ref & $0.986^{*}(41.75 \%)$ & $(0.931,1.044)$ & $0.922(40.25 \%)$ & $(0.885,0.960)$ \\
\hline \multirow{3}{*}{$\begin{array}{c}\text { No Usual } \\
\text { Source of Care }\end{array}$} & Unadjusted & $1(22.00 \%)$ & Ref & $0.737^{* * * *}(17.21 \%)$ & $(0.722,0.752)$ & $0.936^{* * * *}(20.89 \%)$ & $(0.922,0.951)$ \\
\hline & Adjusted $^{\mathrm{a}}$ & $1(21.41 \%)$ & Ref & $0.921^{* * * *}(20.23 \%)$ & $(0.900,0.942)$ & $0.93^{* * * *}(20.40 \%)$ & $(0.914,0.946)$ \\
\hline & Among the poor ${ }^{a}$ & $1(40.24 \%)$ & Ref & $0.866^{* * *}(37.21 \%)$ & $(0.813,0.923)$ & $0.758^{* * * *}(34.47 \%)$ & $(0.725,0.792)$ \\
\hline \multirow{3}{*}{$\begin{array}{l}\text { Unmet Need } \\
\text { due to cost }\end{array}$} & Unadjusted & $1(15.56 \%)$ & Ref & $0.894^{* * * *}(14.15 \%)$ & $(0.876,0.913)$ & $1.157^{* * * *}(17.57 \%)$ & $(1.139,1.175)$ \\
\hline & Adjusted $^{\mathrm{a}}$ & $1(15.54 \%)$ & Ref & $1.033^{* *}(15.93 \%)$ & $(1.009,1.058)$ & $1.035^{* * * *}(15.95 \%)$ & $(1.016,1.054)$ \\
\hline & Among the poor ${ }^{\mathrm{a}}$ & $1(35.83 \%)$ & Ref & $1.042(36.76 \%)$ & $(0.983,1.01)$ & $0.966^{* * * *}(35.19 \%)$ & $(0.928,1.006)$ \\
\hline \multirow{3}{*}{$\begin{array}{c}\text { No Receipt of a } \\
\text { Routine } \\
\text { Checkup }\end{array}$} & Unadjusted & $1(34.28 \%)$ & Ref & $0.943^{* * *}(32.97 \%)$ & $(0.929,0.957)$ & $1.139^{* * * *}(37.27 \%)$ & $(1.125,1.153)$ \\
\hline & Adjusted $^{\mathrm{a}}$ & $1(34.13 \%)$ & Ref & $1.057^{* * * *}(35.31 \%)$ & $(1.040,1.075)$ & $1.082^{* * * *}(35.81 \%)$ & (1.067 1.097) \\
\hline & Among the poor ${ }^{a}$ & $1(41.75 \%)$ & Ref & $1.06^{* *}(43.1 \%)$ & $(1.001,1.125)$ & $1.03(42.41 \%)$ & $(0.988,1.074)$ \\
\hline
\end{tabular}

SOURCE Authors' analysis of data from the Behavioral Risk Factor Surveillance System, 2005-15 (see Note 16 in text). NOTE Analysis uses Suburban

Definition 2 (see Appendix Exhibit A3). ${ }^{a}$ Analysis adjusted for year, education, employment, marriage status, age, race, ethnicity, state and Federal Poverty

Level category. CI is confidence interval ${ }^{* *} \mathrm{p}<0.5^{* * *} \mathrm{p}<.01{ }^{* * * *} \mathrm{p}<.001$ 
Appendix Exhibit A8: Predicted Probabilities and Odds Ratios for Coverage and Access to Care Barriers, in urban, suburban and rural areas of the United States (Suburban Definition 3)

\begin{tabular}{|c|c|c|c|c|c|c|c|c|c|}
\hline & & Urban ( & & Inner Suburb & & Outer Suburb & & Rural & \\
\hline & & $\begin{array}{l}\text { Odds Ratio } \\
\text { (Predicted } \\
\text { Probability) }\end{array}$ & $95 \% \mathrm{Cl}$ & $\begin{array}{l}\text { Odds Ratio } \\
\text { (Predicted } \\
\text { Probability) }\end{array}$ & $95 \% \mathrm{Cl}$ & $\begin{array}{l}\text { Odds Ratio } \\
\text { (Predicted } \\
\text { Probability) }\end{array}$ & $95 \% \mathrm{Cl}$ & $\begin{array}{l}\text { Odds Ratio } \\
\text { (Predicted } \\
\text { Probability) }\end{array}$ & $95 \% \mathrm{Cl}$ \\
\hline \multirow{3}{*}{ Uninsured } & Unadjusted & $1(18.64 \%)$ & Ref & $0.784^{* * * *}(15.23 \%)$ & $\begin{array}{l}(0.767, \\
0.801)\end{array}$ & $0.745^{* * * *}(14.58 \%)$ & $\begin{array}{l}(0.767 \\
0.801)\end{array}$ & $1.117^{* * * *}(20.38 \%)$ & $\begin{array}{c}(1.097, \\
1.13)\end{array}$ \\
\hline & Adjusted $^{\mathrm{a}}$ & $1(16.81 \%)$ & Ref & 1.009 (16.91\%) & $\begin{array}{c}(0.984 \\
1.034)\end{array}$ & $1.065^{* * * *}(17.54 \%)$ & $\begin{array}{c}(1.036, \\
1.094)\end{array}$ & $1.194^{* * * *}(18.91 \%)$ & $\begin{array}{l}(1.169, \\
1.219)\end{array}$ \\
\hline & $\begin{array}{c}\text { Among the } \\
\text { poor }^{\mathrm{a}}\end{array}$ & $1(41.87 \%)$ & Ref & $1.027(42.45 \%)$ & $\begin{array}{c}(0.974 \\
1.083) \\
\end{array}$ & 0.995 (41.74\%) & $\begin{array}{c}(0.937 \\
1.058) \\
\end{array}$ & $0.930^{* * *}(40.23 \%)$ & $\begin{array}{l}(0.890 \\
0.972)\end{array}$ \\
\hline \multirow{3}{*}{$\begin{array}{l}\text { No Usual } \\
\text { Source of } \\
\text { Care }\end{array}$} & Unadjusted & $1(23.47 \%)$ & Ref & $0.815^{* * * *}(20.00 \%)$ & $\begin{array}{c}(0.9 \\
0.938)\end{array}$ & $0.678^{* * * *}(17.21 \%)$ & $\begin{array}{l}(0.663 \\
0.692)\end{array}$ & $0.861^{* * * *}(20.89 \%)$ & $\begin{array}{l}(0.847, \\
0.876)\end{array}$ \\
\hline & Adjusted $^{\mathrm{a}}$ & $1(21.84 \%)$ & Ref & $0.927^{* * * *}(20.75 \%)$ & $\begin{array}{l}(0.908 \\
0.947)\end{array}$ & $0.893^{* * * *}(20.22 \%)$ & $\begin{array}{l}(0.872 \\
0.915)\end{array}$ & $0.903^{1^{* * *}}(20.38 \%)$ & $\begin{array}{l}(0.886, \\
0.921)\end{array}$ \\
\hline & $\begin{array}{c}\text { Among the } \\
\text { poor }^{\mathrm{a}}\end{array}$ & $1(40.92 \%)$ & Ref & $0.915^{* * *}(39.03 \%)$ & $\begin{array}{c}(0.866 \\
0.966)\end{array}$ & $0.84^{* * * *}(36.23 \%)$ & $\begin{array}{l}(0.786 \\
0.897)\end{array}$ & $0.736^{* * *} *(34.52 \%)$ & $\begin{array}{l}(0.701, \\
0.772)\end{array}$ \\
\hline \multirow{3}{*}{$\begin{array}{l}\text { Unmet Need } \\
\text { due to cost }\end{array}$} & Unadjusted & $1(16.58 \%)$ & Ref & $0.830^{* * * *}(14.16 \%)$ & $\begin{array}{l}(0.813 \\
0.848)\end{array}$ & $0.829^{* * * *}(14.15 \%)$ & $\begin{array}{l}(0.811 \\
0.847)\end{array}$ & $1.072^{* * * *}(17.577 \%)$ & $\begin{array}{c}(1.054 \\
1.091)\end{array}$ \\
\hline & Adjusted $^{\mathrm{a}}$ & $1(15.64 \%)$ & Ref & $0.994(15.57 \%)$ & $\begin{array}{l}(0.971 \\
1.017)\end{array}$ & $1.021(15.88 \%)$ & $\begin{array}{l}(0.996, \\
1.047)\end{array}$ & $1.016(15.82 \%)$ & $\begin{array}{l}(0.996, \\
1.036)\end{array}$ \\
\hline & $\begin{array}{c}\text { Among the } \\
\text { poor }^{\mathrm{a}}\end{array}$ & $1(35.61 \%)$ & Ref & $1.027(36.22 \%)$ & $\begin{array}{c}(0.975 \\
1.084)\end{array}$ & $1.049(36.77 \%)$ & $\begin{array}{c}(0.989 \\
1.113)\end{array}$ & 0.975 (35.18\%) & $\begin{array}{c}(0.933 \\
1.018) \\
\end{array}$ \\
\hline \multirow{3}{*}{$\begin{array}{l}\text { No Receipt } \\
\text { of a Routine } \\
\text { Checkup }\end{array}$} & Unadjusted & $1(33.78 \%)$ & Ref & $1.017^{* *}(34.51 \%)$ & $\begin{array}{l}(1.002 \\
1.033)\end{array}$ & $0.95^{* * *}(32.97 \%)$ & $\begin{array}{l}(0.935 \\
0.964)\end{array}$ & $1.147^{* * * *}(37.26 \%)$ & $\begin{array}{l}(1.132 \\
1.163)\end{array}$ \\
\hline & Adjusted $^{\mathrm{a}}$ & $1(33.94 \%)$ & Ref & $1.021^{* * *}(34.37 \%)$ & $\begin{array}{c}(1.004, \\
1.037)\end{array}$ & $1.067^{* * * *}(35.32 \%)$ & $\begin{array}{c}(1.048 \\
1.086)\end{array}$ & $1.091^{* * * *}(36.02 \%)$ & $\begin{array}{l}(1.075 \\
1.108)\end{array}$ \\
\hline & $\begin{array}{c}\text { Among the } \\
\text { poor }^{\mathrm{a}}\end{array}$ & $1(41.51 \%)$ & Ref & $1.03(42.17 \%)$ & $\begin{array}{c}(0.977 \\
1.086)\end{array}$ & $1.052^{* *}(43.09 \%)$ & $\begin{array}{c}(1.008, \\
1.139)\end{array}$ & $0.980^{* * *}(42.40 \%)$ & $\begin{array}{c}(0.994 \\
1.089)\end{array}$ \\
\hline
\end{tabular}

SOURCE Authors' analysis of data from the Behavioral Risk Factor Surveillance System, 2005-15 (see Note 16 in text). NOTE Analysis uses suburban Definition 3 (see Appendix Exhibit A3). a Analysis adjusted for year, education, employment, marriage status, age, race, ethnicity, state and Federal Poverty Level category. CI is confidence interval ${ }^{* *} \mathrm{p}<0.5^{* * *} \mathrm{p}<.01^{* * * *} \mathrm{p}<.001$ 
Appendix Exhibit A9: Predicted Probabilities and Odds Ratios for Coverage and Access to Care Barriers, in urban, suburban and rural areas of the United States, with Clustering

\begin{tabular}{|c|c|c|c|c|c|c|c|}
\hline & & \multicolumn{2}{|c|}{ Urban (Ref) } & \multicolumn{2}{|c|}{ Suburban } & \multicolumn{2}{|c|}{ Rural } \\
\hline & & $\begin{array}{l}\text { Odds Ratio } \\
\text { (Predicted } \\
\text { Probability) }\end{array}$ & $95 \% \mathrm{Cl}$ & $\begin{array}{l}\text { Odds Ratio } \\
\text { (Predicted } \\
\text { Probability) }\end{array}$ & $95 \% \mathrm{Cl}$ & $\begin{array}{l}\text { Odds Ratio } \\
\text { (Predicted } \\
\text { Probability) }\end{array}$ & $95 \% \mathrm{Cl}$ \\
\hline \multirow{3}{*}{ Uninsured } & Unadjusted & $1(18.66 \%)$ & Ref & $0.770^{* *}(14.99 \%)$ & $(0.611,0.970)$ & $1.117(20.37 \%)$ & $(0.904,1.379)$ \\
\hline & Adjusted $^{\mathrm{a}}$ & 1 (16.99\%) & Ref & $0.973(16.67 \%)$ & $(0.773,1.225)$ & $1.230^{* *}(19.52 \%)$ & $(1.016,1.489)$ \\
\hline & Among the poor ${ }^{a}$ & $1(40.84 \%)$ & Ref & $1.014(41.15 \%)$ & $(0.695,1.48)$ & $1.187(44.81 \%)$ & $(0.886,1.59)$ \\
\hline \multirow{3}{*}{$\begin{array}{c}\text { No Usual } \\
\text { Source of Care }\end{array}$} & Unadjusted & $1(23.47 \%)$ & Ref & $0.765^{* *}(19.01 \%)$ & $(0.591,0.99)$ & $0.859^{* * * *}(20.86 \%)$ & $(0.712,1.042)$ \\
\hline & Adjusted $^{\mathrm{a}}$ & $1(22.03 \%)$ & Ref & $0.878(20.15 \%)$ & $(0.746,1.034)$ & $0.932(21.0 \%)$ & $(0.805,1.079)$ \\
\hline & Among the poor ${ }^{a}$ & $1(40.40 \%)$ & Ref & $0.908(38.34 \%)$ & $(0.744,1.107)$ & $0.815^{* * * *}(36.11 \%)$ & $(0.683,0.973)$ \\
\hline \multirow{3}{*}{$\begin{array}{l}\text { Unmet Need } \\
\text { due to cost }\end{array}$} & Unadjusted & $1(16.68 \%)$ & Ref & $0.830^{* *}(14.16 \%)$ & $(0.716,0.961)$ & $1.072(17.57 \%)$ & $(0.928,1.239)$ \\
\hline & Adjusted $^{\mathrm{a}}$ & $1(15.76 \%)$ & Ref & $0.991(15.51 \%)$ & $(0.873,1.126)$ & $1.051(15.94 \%)$ & $(0.931,1.187)$ \\
\hline & Among the poor ${ }^{a}$ & $1(35.31 \%)$ & Ref & $1.019(35.74 \%)$ & $(0.805,1.29)$ & $1.081(37.17 \%)$ & $(0.897,1.301)$ \\
\hline \multirow{3}{*}{$\begin{array}{l}\text { No Receipt of a } \\
\text { Routine } \\
\text { Checkup }\end{array}$} & Unadjusted & $1(34.11 \%)$ & Ref & $0.993(33.96 \%)$ & $(0.869,1.134)$ & $1.147^{* *}(37.26 \%)$ & $(1.011,1.302)$ \\
\hline & Adjusted $^{\mathrm{a}}$ & $1(34.31 \%)$ & Ref & $0.985(34.17 \%)$ & $(0.892,1.088)$ & $1.072(36.29 \%)$ & $(0.97,1.184)$ \\
\hline & Among the poor ${ }^{a}$ & 1 (41.66\%) & Ref & $0.998(41.69 \%)$ & $(0.878,1.134)$ & $1.060(43.46 \%)$ & $(0.932,1.205)$ \\
\hline
\end{tabular}

SOURCE Authors' analysis of data from the Behavioral Risk Factor Surveillance System, 2005-15 (see Note 16 in text) NOTE Analysis uses suburban

Definition 1, in the text. ${ }^{a}$ Analysis adjusted for year, education, employment, marriage status, age, race, ethnicity, state and Federal Poverty Level category. CI is confidence interval. Analysis used robust standard errors, with clusters at the state and geography level. CI is confidence interval. ${ }^{* *} \mathrm{p}<0.5^{* * *} \mathrm{p}<.01^{* * * *} \mathrm{p}<.001$ 